\title{
Dampak Pandemi Covid-19 terhadap Peternakan Hewan Qurban di Kota Sukabumi dan Kabupaten Bogor, Studi Kasus: Zona Hijau dan Merah
}

\author{
The Impact of Covid-19 Pandemic on the Sacrificial Animal Farm at Sukabumi City and Bogor Regency, \\ Case Study: Green and Red Zone
}

\author{
A. Hakim*, P. Sembada, \& S. D. S. Andik \\ Sekolah Vokasi, Institut Pertanian Bogor \\ Jl. Kumbang No.14 Kampus IPB Cilibende Bogor 16128, Indonesia \\ *Corresponding author: annisahakim@apps.ipb.ac.id \\ (Received 26-05-2021; Revised 29-07-2021; Accepted 01-09-2021)
}

\begin{abstract}
Corona Virus Disease 2019 (Covid-19) has been declared by the World Health Organization (WHO) as a pandemic and Indonesia is one of the countries affected by the outbreak. This has a major impact on the social economic and the prosperous community, especially for sub sector livestock which contributes to the fulfillment of the nutritional value of animal protein and national food security. This study aims to determine the impact of the Covid-19 pandemic on the livestock sector, especially to the sacrificial animal farm. Direct interviews using a questionnaire were conducted with $\mathbf{3 6}$ sacrifial animal farmers in the area of the Covid-19 spread map in the red zone (Bogor Regency) and the green zone (Sukabumi City) from September to November, 2020. The questionnaire was divided into three parts, first part about characteristics of farmers, second part about farming activities, and the last about market of sacrificial animals. The pandemic has caused changes in livestock procurement in terms of input prices and sales of sacrificial animals. The price of livestock for the production input during the pandemic in the green zone is low, while in the red zone is high. The decrease in sales occurred in the green zone, while in the red zone is increase, both for sheep and cattle farmers. Most of sacrificial animal farmers $(\mathbf{8 8 . 8 9 \%})$ did not change their sales method from the previous year. Sacrificial animal farmers also strongly agree that Covid-19 pandemic has an impact on the economic conditions of farmers.
\end{abstract}

Keywords: Covid-19, economic impact, sacrificial animal, green zone, red zone

\section{ABSTRAK}

Corona Virus Disease 2019 (Covid-19) telah dinyatakan oleh World Health Organization (WHO) sebagai pandemi dan Indonesia merupakan salah satu negara yang terdampak wabah tersebut. Hal ini berdampak besar pada aspek sosial, ekonomi dan kesejahteraan masyarakat, khususnya sub sektor peternakan yang berkontribusi terhadap pemenuhan nilai gizi protein hewani dan ketahanan pangan secara nasional. Penelitian ini bertujuan mengkaji dampak pandemi Covid-19 terhadap sektor peternakan, khususnya peternak hewan qurban. Wawancara langsung menggunakan kuesioner dilakukan kepada 36 peternak hewan qurban di wilayah peta penyebaran covid-19 pada zona merah (Kabupaten Bogor) dan zona hijau (Kota Sukabumi) pada bulan September sampai dengan November 2020. Kuesioner terdiri dari 3 bagian, yaitu aspek karakteristik peternak, aktivitas beternak, dan pemasaran hewan qurban. Pandemi covid-19 menyebabkan perubahan pada pengadaan ternak dari segi harga input dan penjualan hewan qurban. Harga input produksi ternak selama pandemic covid-19 pada zona hijau megalami penurunan dibandingkan dengan periode qurban tahun sebelumnya, sedangkan pada zona merah mengalami kenaikan harga. Penurunan penjualan terjadi di zona hijau, sedangkan kenaikan penjualan terjadi di zona merah, baik untuk ternak domba maupun sapi. Sebagian besar $(88.89 \%)$ peternak hewan qurban tidak merubah metode penjualan dari tahun sebelumnya. Peternak hewan qurban juga memberikan persepsi sangat setuju bahwa pandemic covid-19 yang terjadi berdampak pada kondisi ekonomi peternak.

Kata kunci: Covid-19, dampak ekonomi, hewan qurban, zona hijau, zona merah 


\section{PENDAHULUAN}

Corona Virus Disease 2019 (Covid-19) telah dinyatakan oleh World Health Organization (WHO) sebagai pandemic dan Indonesia merupakan salah satu negara yang terdampak wabah tersebut. Salah satu upaya pemerintah dalam memutus rantai penyebaran Covid-19 adalah memberlakukan physical distancing melaui program Pembatasan Sosial Berskala Besar (PSBB). Hal ini berdampak pada kehidupan sosial ekonomi masyarakat di Indonesia, salah satu kalangan masyarakat yang terdampak adalah peternak. Sub sektor peternakan berkontribusi terhadap pemenuhan nilai gizi protein hewani dan ketahanan pangan secara nasional. Namun pada masa pandemi ini banyak peternak yang mengalami kerugian akibat terganggunya kegiatan produksi dan distribusi produk.

Indonesia merupakan negara dengan mayoritas masyarakatnya beragama Islam. Setiap tahun masyarakat muslim di Indonesia merayakan Idul Adha dengan menyembelih hewan ternak sebagai rasa syukurnya kepada Allah SWT. Idul Adha merupakan momen yang menguntungkan bagi peternak hewan qurban seperti domba dan sapi, karena penjualan ternak meningkat dari periode biasanya. Selain itu, harga hewan qurban yang dijual lebih tinggi dibandingkan penjualan pada periode selain qurban. Menurut Ibrahim et al. (2019a), Idul Adha memberikan pengaruh yang signifikan dalam penjualan ternak, aktifitas penjualan ternak meningkat sebulan sebelum perayaan Idul Adha dengan harga tinggi sehingga banyak peternak yang mendapatkan keuntungan yang tinggi pada momen ini. Menurut Ibrahim et al. (2019a), alasan peternak banyak melakukan penjualan pada saat Idul Adha adalah harga jual ternak yang tinggi, mudah dalam penjualan, dan banyaknya konsumen.

Idul Adha tahun 2020 berlangsung pada saat terjadi Covid-19, dimana kondisi sosial ekonomi masyarakat mengalami penurunan dibandingkan tahun sebelumnya yang diakibatkan oleh terjadinya penurunan pendapatan sebesar $86.12 \%$ (BPS 2021). Oleh karena itu, penelitian ini dilakukan untuk melihat dampak pandemi Covid-19 terhadap peternak hewan qurban di lokasi zona merah (Kabupaten Bogor) dan zona hijau (Kota Sukabumi) pada peta penyebaran Covid-19 di Jawa Barat.

\section{MATERI DAN METODE}

\section{Waktu dan Lokasi Penelitian}

Penelitian ini dilaksanakan selama 3 bulan, mulai dari bulan September sampai dengan bulan November 2020 di Kota Sukabumi dan Kabupaten Bogor. Kedua daerah tersebut dipilih karena berada pada satu wilayah pembagungan di Jawa Barat (Wilayah I) (BPS 2021). Kota Sukabumi dipilih karena merupakan satu-satunya wilayah dengan status zona hijau di Jawa Barat pada periode pelaksanaan qurban (periode Juli 2020), sedangkan Kabupaten Bogor dipilih karena merupakan salah satu wilayah dengan status zona merah yang berdekatan dengan Kota Sukabumi. Penelitian ini dilaksanakan pada 36 peternak hewan qurban (domba dan sapi).

\section{Materi}

Kuesioner yang digunakan terbagi menjadi tiga aspek, yaitu karakteristik peternak, aktivitas beternak, dan pemasaran hewan qurban.

\section{Penentuan Sampel}

\section{Metode}

Sampel penelitian ini adalah 36 peternak domba dan sapi yang ada di Kota Sukabumi dan Kabupaten Bogor. Pengambilan sampel dilakukan dengan menggunakan metode nonprobability sampling. Peternakan hewan qurban domba dan sapi yang dipilih berada di daerah terdampak covid zona merah (Kabupaten Bogor) dan zona hijau (Kota Sukabumi) berdasarkan peta sebaran kasus covid-19 di Jawa Barat (periode Juli 2020). Setelah itu, dilakukan mapping peternakan di kedua wilayah tersebut untuk menentukan sampel dan mengkategorikannya berdasarkan skala produksi peternakan. Kategori peternakan terdiri dari skala kecil ( $<50$ ekor), skala sedang (50-100 ekor), dan skala besar (>100 ekor).

\section{Pengumpulan Data}

Data yang digunakan dalam penelitian ini meliputi data primer dan data sekunder. Data primer diperoleh melalui wawancara langsung dengan menggunakan kuesioner terstruktur terhadap 36 peternak hewan qurban yang terdiri atas 18 peternak domba dan 18 peternak sapi. Data yang dikumpulkan meliputi karakteristik peternak, aktivitas beternak, penjualan dan metode pemasaran hewan qurban pada kurun waktu satu tahun sebelum pandemi (2019) dan saat pendemi (2020) di dua zona penelitian. Hal ini dilakukan untuk mengidentifikasi ada tidaknya dampak zona penyebaran Covid-19 terhadap aktivitas peternakan hewan qurban di Jawa Barat. Data sekunder digunakan untuk menggali informasi mengenai peta penyebaran covid-19 di Jawa Barat dan kebijakan pemerintah mengenai tatalaksana qurban pada saat pandemic covid-19.

\section{Analisis Data}

Data yang diperoleh dianalisis secara deskriptif untuk mengidentifikasi dampak yang ditimbulkan pandemic Covid-19 terhadap kondisi peternakan hewan qurban di Jawa Barat. Adapun penilaian keputusan peternak dalam pembelian hewan qurban dan pendapat peternak mengenai kepentingan dampak pandemic covid-19 terhadap aktivitas beternaknya menggunakan skala Likert. Sugiyono (2013) mengemukakan bahwa Skala Likert digunakan untuk mengukur sikap, pendapat, maupun persepsi seseorang atau sekelompok orang terhadap suatu fenomena sosial.

\section{HASIL DAN PEMBAHASAN}

\section{Karakteristik Peternak Hewan Qurban di Jawa Barat}

Karakeristik peternak hewan qurban pada penelitian ini tersaji pada Tabel 1. Usia peternak hewan qurban ada pada umur produktif, yaitu pada rentang 15-64 tahun (Kurniawati dan Sugiyanto 2021). Pada kelompok umur tersebut, peternak mampu untuk berpikir dan melakukan pekerjaan dengan baik serta mampu menerima inovasi-inovasi baru sehingga berguna demi kemajuan usahanya (Asmirani et al. 2014). Pada zona hijau penyebaran covid-19 di Jawa 
Tabel 1. Karakteristik peternak hewan qurban pada dua zona penelitian saat pandemi covid-19 (tahun 2020)

\begin{tabular}{|c|c|c|}
\hline Parameter & $\begin{array}{c}\text { Zona Hijau } \\
(\%)\end{array}$ & $\begin{array}{c}\text { Zona Merah } \\
(\%)\end{array}$ \\
\hline \multicolumn{3}{|l|}{ Usia } \\
\hline 20-30 tahun & 0.0 & 44.4 \\
\hline 31-40 tahun & 27.8 & 33.3 \\
\hline 41-50 tahun & 44.4 & 11.1 \\
\hline$>50$ tahun & 27.8 & 11.1 \\
\hline \multicolumn{3}{|l|}{ Tingkat Pendidikan } \\
\hline Sekolah Dasar (SD) & 50.0 & 11.1 \\
\hline $\begin{array}{l}\text { Sekolah Menengah Pertama } \\
\text { (SMP) }\end{array}$ & 11.1 & 16.7 \\
\hline $\begin{array}{l}\text { Sekolah Menengah Atas } \\
\text { (SMA) }\end{array}$ & 11.1 & 44.4 \\
\hline Perguruan Tinggi & 27.8 & 27.8 \\
\hline \multicolumn{3}{|l|}{ Pengalaman Beternak } \\
\hline$<5$ tahun & 11.1 & 11.1 \\
\hline 5-10 tahun & 22.2 & 50.0 \\
\hline 11-20 tahun & 33.3 & 22.2 \\
\hline$>20$ tahun & 33.3 & 5.6 \\
\hline \multicolumn{3}{|l|}{ Status Usaha Peternakan } \\
\hline Utama & 44.4 & 100.0 \\
\hline Sampingan & 55.6 & 0.0 \\
\hline
\end{tabular}

Barat didominasi oleh usia 41-50 tahun, yaitu sebanyak 44.4\% dengan mayoritas pendidikan formal terakhir adalah Sekolah Dasar (50\%). Sedangkan mayoritas peternak hewan qurban pada zona merah merupakan peternak muda dengan rentang usia 20-30 tahun dengan pendidikan formal terakhir Sekolah Menengah Atas (44.4\%). Asmirani et al. (2014) menyatakan bahwa peternak dengan tingkat pendidikan rendah akan menyebabkan kemampuan dalam mengadopsi suatu teknologi akan terhambat, sebaliknya dengan memiliki pendidikan yang tinggi dapat memberikan pemikiran yang positif kepada peternak sehingga lebih antusias untuk melakukan sesuatu guna mengembangkan usahanya. Pengalaman beternak pada zona hijau yang sudah cukup lama, yaitu lebih dari 11-20 tahun dan lebih dari 20 tahun dengan proporsi yang sama, yaitu $44,4 \%$, sedangkan sebanyak $50 \%$ peternak pada zona merah memiliki pengalaman beternak 5-10 tahun. Pengalaman beternak merupakan suatu hal yang sangat mendasari seseorang dalam mengembangkan usahanya dan sangat berpengaruh terhadap keberhasilan usaha (Asmirani et al. 2014).

Pekerjaan utama peternak hewan qurban pada zona hijau diantaranya sebagai pengusaha, pedagang, pegawai swasta, dan buruh. Usaha peternakan hewan qurban di zona hijau sebagian besar merupakan usaha sampingan, yaitu sebesar 55.6\%. Hal ini sesuai dengan pendapat Asmirani et al. (2014) yang menyatakan bahwa peternakan bukan merupakan usaha pokok, tetapi merupakan usaha sampingan atau sebagai tabungan keluarga yang setiap saat dapat diuangkan. Peternak pada zona merah melakukan aktivitas beternak sebagai usaha pokoknya, sehingga hal ini menjadi sumber penghasilan utamanya.

\section{Aktivitas Beternak}

\section{Sistem Produksi Peternakan}

Hewan ternak yang banyak dijual sebagai hewan qurban di Indonesia diantaranya domba, kambing, dan sapi. Aktivitas beternak pada peternakan yang dijadikan sebagai objek penelitian ini dapat dilihat pada Tabel 2. Peternakan hewan qurban melakukan berbagai sistem produksi. Tabel 2 memperlihatkan bahwa sistem produksi peternakan yang diterapkan responden penelitian ini diklasifikasikan menjadi 3 , diantaranya penggemukan, pembibitan dan pembesaran, serta pembesaran dan penggemukan. Hasil penelitian menunjukkan bahwa lebih dari $60 \%$ peternakan hewan qurban di Jawa Barat, baik peternakan domba maupun sapi melakukan sistem produksi penggemukan. Hal ini dinilai lebih menguntungkan untuk peternak karena memerlukan waktu yang singkat dalam pemeliharaannya (rataan 3 bulan pemeliharaan), sehingga biaya produksi yang dikeluaran rendah. Selain itu, pada momen idul Adha peternak mengharapkan keuntungan yang lebih tinggi dibandingkan dengan hari biasanya, sehingga dengan melakukan system produksi penggemukan, keuntungan yang didapatkan menjadi semakin tinggi.

Tabel 2. Aktivitas beternak peternak hewan qurban pada dua zona penelitian saat pandemi covid-19 (tahun 2020)

\begin{tabular}{lcc}
\hline Variabel & $\begin{array}{c}\text { Peternak Sapi } \\
(\%)\end{array}$ & $\begin{array}{c}\text { Peternak Domba } \\
(\%)\end{array}$ \\
\hline Sistem Produksi & & \\
Penggemukan & 77.7 & 72.2 \\
Pembibitan + Pembesaran & 5.6 & 5.6 \\
Pembesaran + Penggemu- & 16.7 & 22.2 \\
kan & & \\
Total & 100 & 100 \\
\hline Pasokan Input & & \\
Pembibitan sendiri & 2.8 & 2.8 \\
Peternak rakyat & 16.2 & 22.8 \\
Belantik & 18.9 & 25.7 \\
Supplier ternak & 21.6 & 20.0 \\
Pasar Ternak & 40.5 & 28.7 \\
Total & 100 & 100 \\
\hline
\end{tabular}

\section{Pengadaan Input Peternakan}

Peternak hewan qurban di Jawa Barat mendapatkan ternak sebagai input produksinya dari berbagai sumber, seperti melakukan pembibitan sendiri, dari peternak rakyat, belantik, supplier ternak, dan pasar ternak. Tabel 2 menunjukkan bahwa mayoritas peternak, baik peternak sapi maupun domba membeli input produksinya dari pasar ternak. Pasar ternak dipilih karena berbagai alasan, seperti tersedianya ternak dengan berbagai jenis pilihan, baik dari segi harga, bangsa, umur, jenis kelamin, bobot dan kondisi ternaknya sehingga peternak memiliki kesempatan memilih sesuai dengan kebutuhannya. Hal ini sesuai dengan 
penelitian yang dilakukan oleh Ibrahim et al. (2019a) yang menyatakan bahwa pasar hewan merupakan tempat yang sering digunakan untuk pengadaan ternak karena terdapat berbagai jenis ternak dan pilihan harga.

Keputusan peternak dalam melakukan pembelian input produksi ditunjukkan pada Gambar 1. Kondisi ternak merupakan hal yang sangat penting diperhatikan dalam pengadaan ternak, khususunya untuk dijadikan hewan qurban (sekitar $80 \%$ peternak menyatakan setuju). Hal ini dikarenakan ternak yang akan dijadikan sebagai hewan qurban harus memenuhi persyaratan tertentu. Budisatria et al. (2019) menyatakan bahwa persyaratan ternak sebagai hewan qurban, diantaranya sehat, tidak cacat, tidak bunting, tidak dikastrasi, ekor tidak putus, tanduk tidak patah, dan telah cukup umur. Hasil penelitian ini juga sejalan dengan penelitian Ibrahim et al. (2019b) bahwa kondisi ternak merupakan kriteria utama (sebesar 86.11\%) dalam preferensi konsumen saat memilih hewan qurbannya, sehingga peternak harus dapat menyediakan hewan yang sesuai dengan keinginan konsumen.

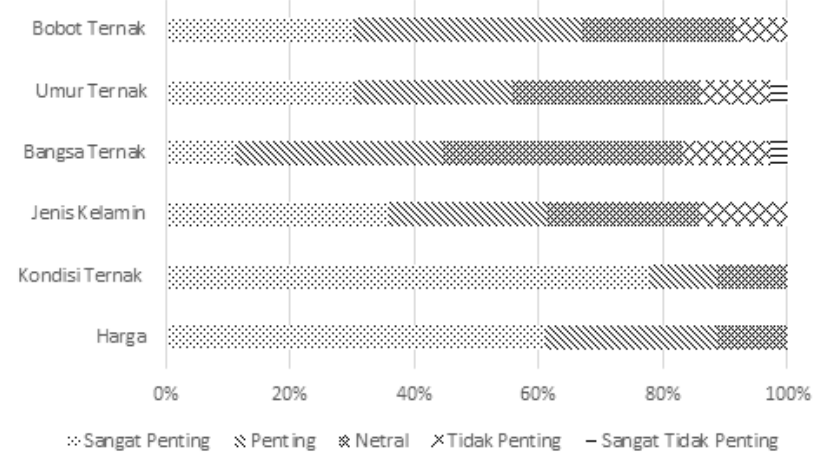

Gambar 1. Faktor-faktor yang mempengaruhi keputusan peternak dalam pembelian pasokan input ternak

\section{Kondisi Pengadaan Input Peternakan Hewan Qurban pada saat Pandemi Covid-19}

Kondisi pasokan hewan qurban pada dua zona penelitian dapat dilihat pada Tabel 3. Berdasarkan hasil wawancara, harga input pasok hewan qurban pada masa pandemic di zona hijau cenderung turun, baik untuk sapi maupun domba/kambing. Sedangkan harga input pasok untuk ternak qurban pada zona merah naik dari periode qurban sebelumnya. Namun kemudahan peternak dalam pembelian input pasok baik pada zona hijau, maupun zona merah masih mudah didapatkan. Perbedaan harga tersebut disebabkan oleh kondisi transportasi Pengadaan hewan ternak pada zona merah terhambat karena adanya pemberlakuan PSBB (Pembatasan Sosial Berskala Besar) yang dicanangkan pemerintah, khususnya untuk daerah terdampak Covid-19 zona merah yang cukup ketat. Hal ini menyebabkan peternak hewan qurban di zona merah yang sebelumnya membeli hewan qurban dari luar daerah karena harganya yang lebih murah menjadi terhambat sehingga pembelian input produksi banyak dilakukan di wilayah Bogor dengan harga yang cukup tinggi. Hal ini menyebabkan harga input pasok di zona merah meningkat
Tabel 3. Kondisi input pasok hewan qurban pada dua zona penelitian saat pandemi Covid-19 (Tahun 2020)

\begin{tabular}{lcccc}
\hline Variabel & \multicolumn{2}{c}{ Zona Hijau } & \multicolumn{2}{c}{ Zona Merah } \\
\cline { 2 - 5 } & $\begin{array}{c}\text { Sapi } \\
(\%)\end{array}$ & $\begin{array}{c}\text { Domba } \\
(\%)\end{array}$ & $\begin{array}{c}\text { Sapi } \\
(\%)\end{array}$ & $\begin{array}{c}\text { Domba } \\
(\%)\end{array}$ \\
\hline Harga Input & & & & \\
Naik & 33.3 & 33.3 & 77.8 & 88.9 \\
Turun & 55.6 & 44.4 & 0.0 & 0.0 \\
Tetap & 11.1 & 22.2 & 22.2 & 11.1 \\
\hline Supply ternak & & & & \\
Sulit & 22.2 & 11.1 & 44.4 & 44.4 \\
Mudah & 77.8 & 88.9 & 55.6 & 55.6 \\
\hline
\end{tabular}

dari periode qurban sebelumnya. Harga input pada zona hijau rendah dikarenakan banyak peternak rakyat yang menjual murah ternaknya akibat kebutuhan ekonomi yang mendesak selama pandemi Covid-19. Selain itu, dikarenakan zona hijau berlokasi di Sukabumi, peternak disana kesulitan memasarkan ternaknya keluar Sukabumi, seperti ke daerah Jabotabek yang biasanya menjadi kota tujuan pemasaran peternak di Sukabumi. Sehingga peternak di wilayah zona hijau diuntungkan oleh kondisi ini karena mendapatkan input produksi yang harganya lebih rendah.

\section{Penjualan dan Metode Pemasaran Hewan Qurban}

\section{Penjualan Hewan Qurban}

Tren penjualan hewan qurban selalu mengalami peningkatan dari tahun ke tahun, namun karena adanya pandemi Covid-19 tren penjualan tersebut berubah, dikarenakan adanya perubahan pada kondisi social ekonomi peternak yang terdampak Covid-19. Hal ini sejalan dengan data BPS (2020) yang menunjukkan bahwa terjadi penurunan pemotongan ternak pada periode Idul Adha dari tahun sebelumnya yaitu sebesar $12.90 \%$ untuk ternak sapi dan $7.16 \%$ untuk ternak domba. Tabel 4 menunjukkan perubahan penjualan hewan qurban sebelum dan setelah pandemic pada zona penyebaran Covid-19 di Jawa Barat. Penurunan penjualan terjadi di zona hijau, baik pada peternakan domba maupun sapi dengan berbagai skala produksi. Penurunan tertinggi, yaitu sebesar $48.08 \%$ terdapat pada peternakan domba skala besar. Berdasarkan hasil wawancara, penurunan volume penjualan ternak tersebut diakibatkan oleh sulitnya melakukan pengiriman ternak ke luar kota dikarenakan adanya PSBB sehingga penjualan ternak terbatas pada konsumen yang masih ada dalam satu wilayah, sedangkan konsumen sebelumnya banyak yang dari luar kota Sukabumi. Selain itu, daya beli konsumen yang menurun juga berpengaruh terhadap penjualan domba pada skala besar. Sebaliknya, peternak sapi skala kecil di zona hijau mengalami kenaikan penjualan sebesar $10.25 \%$. Hal ini disebabkan harga input sapi di zona hijau rendah dibandingkan tahun sebelumnya (2019) dan permintaan akan ternak sapi di wilayah sekitar peternakan mengalami peningkatan. Faktor lain yang menyebabkan penurunan penjualan hewan qurban di zona hijau adalah banyaknya peternak yang ekonominya terdampak Covid-19 karena 
Hakim et al.

Jurnal Ilmu Produksi dan Teknologi Hasil Peternakan 9 (3): 120-126

Tabel 4. Perubahan penjualan hewan qurban sebelum dan setelah pandemi pada dua zona penelitian saat pandemi Covid-19 (tahun 2020)

\begin{tabular}{|c|c|c|c|c|c|c|}
\hline \multirow[t]{2}{*}{ Kapasitas produksi } & \multicolumn{2}{|c|}{ Zona hijau } & \multirow[t]{2}{*}{ Perubahan (\%) } & \multicolumn{2}{|c|}{ Zona merah } & \multirow[t]{2}{*}{ Perubahan (\%) } \\
\hline & 2019 (ekor) & 2020 (ekor) & & 2019 (ekor) & 2020 (ekor) & \\
\hline \multicolumn{7}{|l|}{ Sapi } \\
\hline Kecil & 65.00 & 63.33 & -2.57 & 34.67 & 26.67 & -23.07 \\
\hline Sedang & 88.00 & 97.02 & 10.25 & 60.00 & 70.00 & 16.67 \\
\hline Besar & 138.00 & 123.33 & -10.63 & 243.67 & 251.33 & 3.14 \\
\hline \multicolumn{7}{|l|}{ Domba } \\
\hline Kecil & 14.33 & 10.67 & -25.54 & 26.67 & 40.00 & 49.98 \\
\hline Sedang & 70.00 & 56.67 & -19.04 & 350.00 & 233.33 & -33.33 \\
\hline Besar & 866.67 & 450.00 & -48.08 & 1233.33 & 1733.33 & 40.54 \\
\hline
\end{tabular}

peternakannya hanya sebatas usaha sampingan, sehingga peternak tidak memiliki cukup modal untuk membeli input produksi sehingga penjualannya pun menurun dari tahun sebelumnya.

Kondisi penjualan hewan qurban di zona hijau mengalami peningkatan dari tahun sebelumnya, kecuali pada peternak sapi skala kecil dan peternak domba skala sedang yang mengalami penurunan. Peningkatan penjualan hewan qurban tertinggi adalah pada peternak domba skala kecil dan besar, dengan masing-masing kenaikan adalah sebesar $49.98 \%$ dan $40.54 \%$ dari tahun sebelumnya. Hal ini dikarenakan peternak di zona merah merupakan usaha utama sehingga peternak focus mengembangkan usahanya. Selain itu, peternak-peternak tersebut sudah memiliki pelanggan tetap dan kondisi PSBB menyebabkan konsumen hewan qurban di zona merah terfokus melakukan pembelian pada peternakan yang ada di wilayah tersebut. Penurunan penjualan hewan qurban terjadi pada peternak sapi skala kecil, hal ini disebabkan peternak sapi tersebut tidak memiliki cukup modal untuk membeli input produksi dan tidak memiliki konsumen langganan sehingga mengalami kesulitan dalam menjual ternaknya.

\section{Metode Pemasaran Hewan Qurban}

Hasil penelitian menunjukkan bahwa pemasaran hewan qurban dilakukan ke berbagai pihak, diantaranya kepada konsumen akhir (end user), reseller, Lembaga atau Yayasan, dan ke sesama peternak lainnya (Gambar 2). Seluruh peternak hewan qurban melakukan penjualan langsung ke end user.

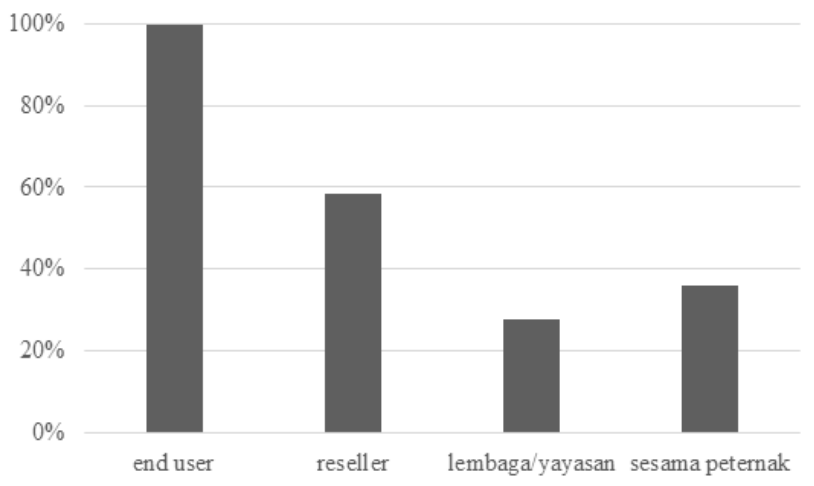

Gambar 2. Pembeli hewan qurban pada dua zona penelitian saat pandemi Covid-19 (tahun 2020)
Selain melakukan penjualan ke end user, sebesar $58 \%$ peternak juga memiliki reseller atau pihak kedua sebagai penjual hewan qurbannya. Hal ini dirasa cukup efektif dalam penjualan ternak karena memudahkan peternak dalam menjual ternaknya tanpa harus melakukan strategi pemasaran sendiri. Pemasaran hewan qurban ke Lembaga/Yayasan maupun ke peternak lainnya dilakukan oleh peternak skala sedang sampai besar, baik itu peternak sapi maupun peternak domba. Hal ini biasanya dilakukan karena peternak tersebut sudah menjalin kerjasama sebelumnya dengan pihak tersebut.

Metode pemasaran hewan qurban dilakukan secara langsung dan tidak langsung. Pemasaran secara langsung yaitu konsumen datang langsung ke peternakan maupun lapak qurban yang disediakan peternak. Pemasaran tidak langsung yaitu melalui media online, baik itu melalui social media, maupun market place. Media sosial yang banyak digunakan untuk pemasaran hewan qurban adalah aplikasi Whatsapp, Facebook, dan Instagram. Sedangkan marketplace yang digunakan diantaranya Tokopedia, Lazada, Shopee, dan Bukalapak. Pemasaran hewan qurban melalui market-place tersebut dilakukan oleh peternak domba dan sapi skala besar. Sembada et al. (2021) mengemukakan bahwa pembelian hewan qurban mealui media sosial dan market-place mengalami peningkatan yang cukup drastis pada saat pandemi Covid-19 yang merupakan upaca masyarakat dalam meminimalisir penyebaran Covid-19.

Gambar 3 menunjukkan perubahan metode penjualan hewan qurban yang dilakukan peternak pada saat pandemic Covid-19. Data menunjukkan bahwa sebesar $88.89 \%$ peternak tidak melakukan perubahan metode penjualan dari tahun sebelumnya. Sementara itu, sebanyak $11.11 \%$ peternak mengalami perubahan penjualan, yaitu 2.78\% konsumen lebih banyak yang datang langsung ke kandang ataupun lapak qurban, sedangkan $8.33 \%$ peternak lebih banyak menggunakan media social sebagai media penjualan semasa pandemi Covid-19. Berdasarkan data hasil wawancara, peternak yang melakukan perubahan penjualan dengan menggunakan media social adalah peternak skala besar baik sapi maupun domba yang berada pada zona merah. Hal ini dilakukan untuk mengurangi interaksi secara langsung antara peternak sebagai penjual hewan qurban dengan konsumen. 


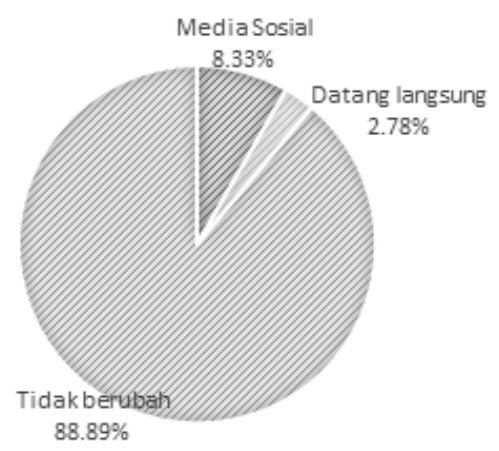

Gambar 3. Perubahan media penjualan hewan qurban pada dua zona penelitian saat pandemi Covid-19 (tahun 2020)

\section{Persepsi Peternak Mengenai Pengaruh Covid-19 terhadap Peternakan Hewan Qurban}

Penelitian ini juga mengidentifikasi persepsi peternak mengenai pengaruh pandemi Covid-19 terhadap beberapa aspek, diantaranya aktivitas beternak, aspek produksi, aspek ekonomi peternak, dan pemasaran hewan ternak. Hasil penelitian (Gambar 4) menunjukkan bahwa sebanyak $61 \%$ peternak menyatakan sangat setuju pandemi Covid-19 berdampak pada kondisi ekonomi peternak. Hal ini ditunjukkan dari banyaknya peternak yang mengurangi produksi karena disebabkan ketidakcukupan modal yang dibutuhkan. Hal ini juga berkaitan dengan persepsi peternak terhadap aktivitas beternak. Sebesar 33\% peternak sangat setuju aktivitas beternak dipengaruhi oleh pandemi Covid-19 yang ditunjukkan dengan pengurangan produksi akibat dari dampak ekonomi yang dirasakan peternak.

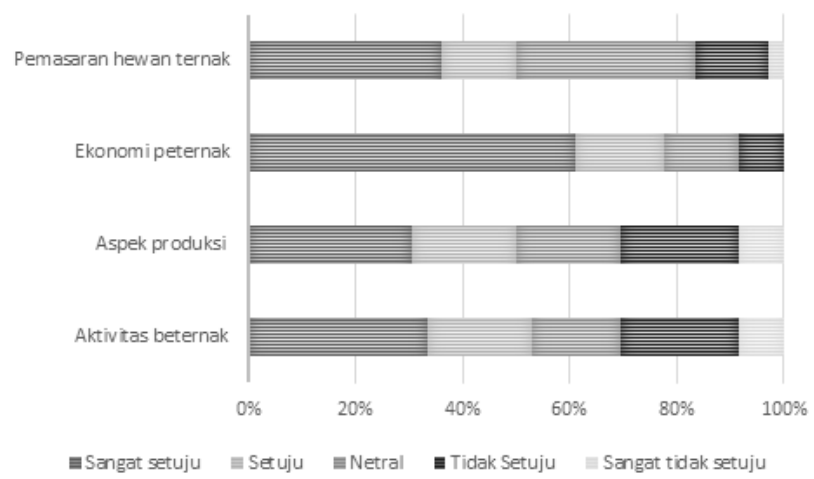

Gambar 4. Persepsi peternak mengenai pengaruh pandemi Covid-19 terhadap kondisi peternakan hewan qurban

Peternak juga sangat setuju bahwa pandemi Covid-19 berdampak pada pemasaran hewan qurban. Hal ini dapat dilihat berdasarkan hasil penelitian (Tabel 4) bahwa perubahan penjualan terjadi di kedua zona penelitian, baik itu pada peternakan sapi atau domba dengan skala kecil sampai besar. Sebesar 56.32\% kendala yang dihadapi berbagai sektor usaha yang ada di Jawa Barat adalah pada pemasaran dan sebanyak 29.95\% sektor usaha di Jawa Barat mengubah metode pemasarannya dari yang konvesional menjadi memanfaatkan teknologi dan internet (BPS 2021).

Hasil penelitian juga menunjukkan sebesar 30\% peternak sangat setuju bahwa aspek produksi peternakan dipengaruhi oleh pandemi Covid-19. Berdasarkan hasil penelitian, aspek produksi yang dipengaruhi pandemi Covid-19 adalah pada pengadaan input bakalan (Tabel 3). Pengadaan input bakalan pada zona hijau cenderung mengalami penurunan, karena didapatkan dari sesame peternak yang menjual produknya dengan harga rendah. Hal ini didukung oleh data BPS (2021) yang menunjukkan bahwa pada sector pertanian, kehutanan, peternakan dan perikanan di Jawa Barat mengalami penurunan harga produk yang dihasilkan, yaitu sebesar $52.20 \%$.

\section{KESIMPULAN}

Pandemi Covid-19 menyebabkan beberapa perubahan pada sub sektor peternakan, yaitu pada peternak hewan qurban di Kota Sukabumi dan Kabupaten Bogor. Perubahan yang terjadi diantaranya pada aktivitas beternak, seperti pengadaan input produksi dan pada penjualan hewan qurban. Penurunan harga input produksi terjadi di wilayah zona hijau, sedangkan kenaikan harga input produksi terjadi pada wilayah zona merah. Sedangkan dari sisi penjualan penurunan penjualan hewan qurban terjadi di wilayah zona hijau, baik itu peternakan sapi maupun domba pada skala kecil hingga besar. Sedangkan wilayah zona merah terjadi peningkatan penjualan hewan qurban, dengan peningkatan penjualan yang tinggi pada peternak domba skala kecil dan besar. Peternak hewan qurban juga memberikan persepsi sangat setuju bahwa pandemi Covid-19 yang terjadi berdampak pada kondisi ekonomi peternak.

\section{UCAPAN TERIMA KASIH}

Ucapan terima kasih disampaikan kepada Sekolah Vokasi IPB University yang telah mendanai penelitian ini dan peternak hewan qurban sebagai responden yang terlibat dalam penelitian ini.

\section{DAFTAR PUSTAKA}

Asmirani, A., S. Dwijatmiko, \& W. Sumekar. 2014. Faktor-faktor yang mempengaruhi aktivitas budidaya ternak sapi potong di kabupaten buru. Agrinimal. 4(1):28-37

BPS (Badan Pusat Statistik). 2021. Analisis Hasil Survei Dampak Covid-19 Terhadap Pelaku Usaha Provinsi Jawa Barat. Jakarta(ID): BPS RI. https://jabar.bps.go.id/ publication/2021/04/08/a54fc78d4e561b2719dc851c/ analisis-hasil-survei-dampak-covid-19-terhadappelaku-usaha-provinsi-jawa-barat- periode-12-23januari-2021-.html [5 Agustus 2021]

BPS (Badan Pusat Statistik). 2020. Statistik Pemotongan Ternak Tahun 2020. Jakarta (ID): BPS RI. https://www.bps.go.id/ ublication/2021/05/04/5446d9b3d09a12d6a6d0d9dc/ statistik-pemotongan-ternak-2020.html [24 Mei 2021] 
Budisatria I. G. S., M. D. E. Yulianto, A. Ibrahim, B. A. Atmoko1, \& D. Faqar. 2019. Profil pedagang ruminansia kecil pada periode idul adha di Daerah Istimewa Yogyakarta, Indonesia. Prosiding. Seminar Nasional Program Studi Peternakan Fakultas Pertanian Universitas Sebelas Maret "Peningkatan Produktivitas Ternak Tropis Terpadu Berkelanjutan di Era Revolusi Industri 4.0” 2019. 13 Nov 2019; Surakarta, Indonesia. Surakarta: hlm 100-105.

Kurniawati, E. \& C. Sugiyanto. 2021. Pengaruh struktur umur penduduk terhadap pertumbuhan ekonomi di Indonesia. J. Ekonomi dan Pembangunan Indonesia. 21(1): 41-58

Ibrahim A., W. T. Artama, R. Widayanti, M. D. E. Yulianto, D. Faqar, \& I. G. S. Budisatria. 2019a. Sheep traders preferences on marketing place and their satisfaction during Eid al-Adha period in Yogyakarta, Indonesia. IOP Conf. Ser. Earth Environ. Sci. 372:1-6. doi:10.1088/1755-1315/372/1/012071.
Ibrahim, A., I. G. S. Budisatria, R. Widayanti, \& W. T. Artama. 2019b. Consumer's preferences for sheep attributes for Eid al-Adha celebration in Yogyakarta, Indonesia. IOP Conf. Ser. Earth Environ. Sci. 3870120

Sembada, P. A. Hakim, \& S. D. S. Andik. 2021. Dampak pandemi Covid-19 terhadap tataniaga hewan qurban di Jabodetabek: studi kasis pada Mahir Farm. Jurnal Ilmu Produksi dan Teknologi Hasil Peternakan. 9(2):64-71.

Sugiyono, P. 2013. Metode Penelitian Manajemen. Bandung (ID): CV Alfabeta. 